\title{
Research on strategic emerging industries boosting high quality economic
}

\author{
He JIANG ${ }^{1, a}$, Yonghui CAO ${ }^{* 1, b}$ \\ ${ }^{1}$ Department of Business Administration Guangzhou College of Technology and Business, Guangzhou, China \\ Corresponding author: Yonghui CAO
}

\begin{abstract}
. with the development of knowledge economy and the advancement of economic globalization, strategic emerging industries have become the leading industries for a country or region to achieve sustainable economic growth in the future. They are the high integration of emerging technologies and emerging industries, and the driving force of national economic growth. They play an important guiding and decisive role in the national economic growth and the transformation and upgrading of industrial structure. In recent years, China's strategic emerging industries continue to grow rapidly, and have made remarkable achievements in innovation and development, which play an important role in the national economic growth and the transformation and upgrading of industrial structure, but there are also shortcomings. Based on the current situation of the development of strategic emerging industries, this paper analyzes the role of strategic emerging industries in economic development, and puts forward countermeasures and suggestions for strategic emerging industries to boost high-quality economic development.
\end{abstract}

\section{Introduction}

The position of strategic emerging industries in China's modern industrial system and its contribution to highquality economic development are becoming more and more significant. In order to cope with the changes in world economic competition, the state has made important arrangements in vigorously promoting economic restructuring and industrial upgrading, especially in the development of strategic emerging industries.

In October 2010, the State Council officially issued the "decision on accelerating the cultivation and development of strategic emerging industries", which defined the seven major industries of China's strategic emerging industries, and planned that by 2020, the added value of China's strategic emerging industries would account for about $15 \%$ of GDP. The document forms the basic strategic framework for the development of strategic emerging industries in China, and also marks that the development of strategic emerging industries in China has become a major national strategy.

Since 2011, many government reports have pointed out that China will vigorously cultivate strategic emerging industries, with rapid development of new energy, new materials, biomedicine, high-end equipment manufacturing, and new energy vehicles. In 2012, the "12th Five Year Plan" for the development of national strategic emerging industries, which defined the action route of China's strategic emerging industries in coping with international competition and energy conservation and emission reduction.
During the 13th Five Year Plan period, the development of China's strategic emerging industries is facing the severe challenge of international scientific and technological competition and the urgent need of scientific and technological innovation in the new economic normal. China is in the historical stage of "three phase's superposition" in the period of economic growth shifting, the pain period of economic structural adjustment, and the digestion period of early stimulus policies. The central economic work conference takes "turning development power to new growth point" as one of the four objectives of the new normal. The outline of the 13th five year plan for the national economic and social development of the people's Republic of China puts forward the requirements and plans to enhance the supporting role of emerging industries, cultivate and develop strategic industries, build a new pattern for the development of emerging industries, and improve the development environment of emerging industries. The 13th five year plan of national science and technology innovation has planned the overall idea of scientific and technological innovation, the development goals and main tasks of some strategic emerging industries during the 13th Five Year Plan period.

To sum up, it can be said that in recent years, the state attaches great importance to the development of strategic emerging industries, because the development of strategic emerging industries is an inevitable choice to change China's economic development mode, optimize the industrial structure, and achieve the strategic goal of highquality economic development. Based on this, this paper discusses the theoretical logic and strategic measures of China's strategic emerging industries in boosting the high- 
quality economic development.

\section{Literature review}

In 2009, the concept of strategic emerging industries was put forward at the forum of the State Council on the development of emerging strategic industries, and the relevant connotation was further clarified in the 2010 government work report. The "decision of the State Council on accelerating the cultivation and development of strategic emerging industries" in 2010 clearly defines strategic emerging industries as "industries with intensive knowledge and technology, low consumption of material resources, high growth potential and good comprehensive benefits based on major technological breakthroughs and major development needs, which have a significant leading role in the overall economic and social development and long-term development. In 2016, the "classification of strategic emerging industries (Trial)" was released to further define strategic emerging industries. Based on the industrial classification of national economy, this paper defines the strategic emerging industries[1].

The concept of strategic emerging industry is not created out of thin air. Its theoretical basis comes from the concept of strategic industry put forward by development economist Hirschman, who called the leading industry strategic industry. After that, Chinese scholars also pointed out that strategic industries include pillar industries, leading industries and basic industries[2]. Foreign scholars Forbes mentioned that strategic industries refer to emerging industries that are related to the overall and long-term interests of the national economy and may become the leading or pillar industries in the future. For one of the concepts of emerging industries, there is no uniform and strict definition in the academic community. However, they all believe that emerging industries should be based on new technologies and new technologies, and be in the early stage of the industrial life cycle. They can play a leading role in social development, improve productivity, and change the industrial structure[3]. Compared with traditional industries, they have strong competitive advantages.

Relevant academic research focuses on the current situation and content adjustment of strategic emerging industries:

First, it focuses on the definition of strategic emerging industries or the role of a certain factor in industrial development. Focusing on the selection of key industrial fields, the strategic effect prediction model is constructed to guide the adjustment and optimization of industrial structure; and the role of government's macro-control in the development of emerging industries, such as Chesnais, Scott, Toby harfield, domestic scholars have analyzed the role of government in the development of strategic emerging industries in China from different angles[4].

Secondly, it focuses the problems of industrial innovation ability and industrial layout, the evaluation system of innovation ability is constructed. The results show that the overall innovation ability of the industry is weak, the imbalance of regional development is prominent, and there are innovation short boards in some regions. Technological innovation capability lays the foundation for the generation of comparative advantages of emerging industries, such as the innovation related research based on Joseph Schumpeter's innovation theory, Michael Porter's strategic theory and competitive advantage.

Thirdly, in view of the problem of industrial environment construction, it is considered that the industry is still in the embryonic stage of its life cycle, and it is urgent to actively create market environment and cultivate market demand; it should be committed to building the top-level industrial design and governance framework to guide the healthy development of the industry, so as to cope with various risks associated with the rapid development of emerging industries. In the response of enterprises in competition, insight into the industry environment and decision-making are the important conditions for enterprises to adapt to the new business environment in the process of growth[5].

\section{The value of strategic emerging industries is to high quality economic development}

Speeding up the cultivation and development of strategic emerging industries is great strategic significance to promote China's modernization.

First, accelerating the cultivation and development of strategic emerging industries are an inevitable choice for building a well-off society in an all-round way and realizing sustainable economic development. To build a well-off society in an all-round way and realize sustainable development, we must vigorously develop strategic emerging industries, accelerate the formation of new economic growth points, create more jobs, better meet the growing material and cultural needs of the people, and promote the construction of a resource-saving and environment-friendly society.

Second, accelerating the cultivation and development of strategic emerging industries is an important measure to promote the upgrading of industrial structure and accelerate the transformation of economic development mode. The strategic emerging industries take innovation as the main driving force and have strong radiation belt power. Accelerating the cultivation and development of strategic emerging industries is conducive to accelerating the transformation of economic development mode, promoting the upgrading of traditional industries, and building a modern industrial system from a high starting point, thus realizing the fundamental requirements of adjusting and optimizing the industrial structure.

Third, accelerating the cultivation and development of strategic emerging industries is an urgent need to build new international competitive advantages and grasp the initiative of development. In order to occupy a favorable position in the future international competition, China must speed up the cultivation and development of strategic emerging industries, master key core technologies and related intellectual property rights, and enhance the ability of independent development. 


\section{Specific measures for strategic emerging industries to boost high quality economic development}

To speed up the cultivation and development of strategic emerging industries, we must pay attention to top-level design, take scientific and technological innovation as the central link, take market demand as an important driving force, take international development as a necessary condition, strengthen the cultivation of scientific and technological talents, and improve policy support, so as to promote the high-quality economic development through the healthy development of strategic emerging industries. As shown in Figure 1.

\section{1 continue to strengthen top-level design during the 14th Five Year Plan period from 2021 to 2025}

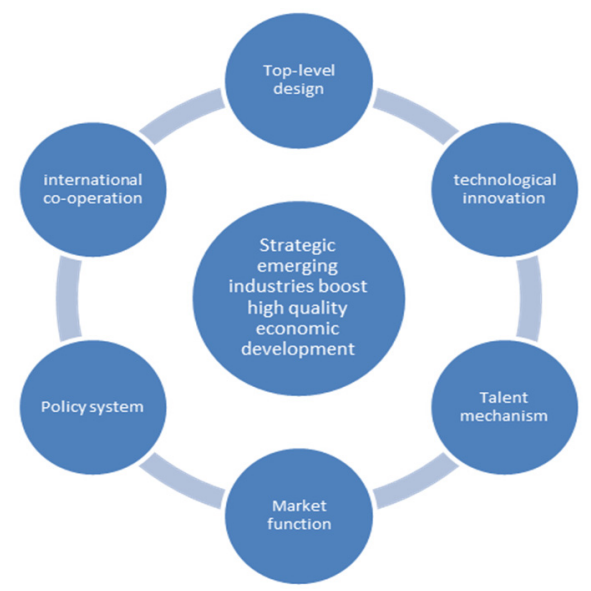

Fig1. Strategic emerging industries boost high quality economic development

We will incorporate strategic emerging industries as an important part of the national "14th five year" plan, and issue a special plan for the development of strategic emerging industries during the 14th five year plan. As China's economic development enters the new normal and high-quality development stage. The driving force of economic growth has shifted from factor driven to innovation driven. It is necessary to further strengthen the cultivation and development of strategic emerging industries, continue to highlight the development of strategic emerging industries in the national "14th five year plan", and issue supporting special plans to promote the industrial structure from low to medium end. In addition, the release and implementation of national strategies such as innovation driven development, coordinated development of Beijing, Tianjin and Hebei, development of Yangtze River economic belt, ecological protection and high-quality development of the Yellow River Basin, construction of Guangdong Hong Kong Macao Bay area, and regional integrated development of Yangtze River Delta are conducive to the layout and development of strategic new industries in the "14th five year plan". In the process of formulating the national "14th five year plan" and the development plan of strategic emerging industries, we should fully consider how to organically combine with the national strategy, and further clarify the positioning, objectives and tasks of the strategic emerging industries in the "14th five year plan". The development trends and changes of international industries should be fully reflected in the national strategic emerging industry planning during the 14th Five Year Plan period.

\section{2 strengthen scientific and technological innovation to enhance the technological capability of strategic emerging industries}

In view of the problems existing in China's strategic emerging industries, such as weak innovation ability of enterprises and lack of mastery of core key technologies, it should strengthen the technological basis of industrial development and strengthen the dominant position of enterprises in innovation around the improvement of enterprises' technological innovation ability and industrial independent development ability. The core work mainly involves six aspects: First, the research on core key technologies and cutting-edge technologies supporting the development of strategic emerging industries should be advanced. The second is to encourage enterprises to build engineering platform with world advanced level and to form engineering and system integration technology capability for industrial chain development. The third is to release China's scientific and technological potential, promote the flow of innovative talents to enterprises and strengthen the talent incentive mechanism. The fourth is take the large-scale development as the goal, coordinate the innovation links, and implement some major industrial innovation and development projects with leading and leading role, so as to form a breakthrough and development advantage. The fifth is vigorously promoted the technology transfer of universities and scientific research institutions, and support enterprises to implement the industrialization of innovation achievements on a large scale. The sixth is to promote the technology, talent, capital and other innovative resources to gather in industrial regions with technological innovation advantages, accelerate the development of strategic emerging industrial bases, and promote the optimization and upgrading of regional industrial structure and economic structure.

\section{3 explore a new incentive mechanism for industrial talents and establish and improve the talent sharing mechanism}

Great changes have taken place in the environment at home and abroad, so it is urgent to explore a matching talent incentive mechanism. First of all, it should give reasonable protection from the material level, effectively solve the basic problems of children's education, housing and medical care of talents in strategic emerging industries, eliminate the worries behind them, and lay a solid foundation for them to devote themselves to industrial innovation and development. Secondly, it should stimulate the fighting spirit from the spiritual level, fully implement the spiritual guidance of people-oriented, respect innovation and value creation, improve the social status 
and identity of industrial talents, pay attention to the guidance of public opinion, and create a good atmosphere for the whole society, especially the teenagers, to respect science and talents. Finally, we should set up industrial talent archives nationwide, improve the part-time talent system, and build a flexible talent sharing mechanism.

\section{4 improve the market supporting service system and make the market play a leading role}

It should focus on promoting strategic emerging industries at the initial stage of development, effectively overcome market entry barriers such as low recognition of product and service market, high cost compared with existing similar products, imperfect market supporting system, and not yet established policy and regulation system. It should give full play to the guiding role of the government, strengthen demonstration application, improve market application supporting service system, and establish and improve market regulation then create a good market environment, transform the demand potential into the driving force of industrial development and play the leading role of the market. Specifically, the first is to organize and implement a number of major application demonstration projects, focusing on the urgent needs of improving people's health level and alleviating the constraints of environmental resources, organizing and implementing the application demonstration projects of national health, green development and information benefit the people, so as to guide the transformation of consumption mode, cultivate the market and promote the industrial development. Second, it should focus on strengthening the construction of market application infrastructure of new energy grid connection and energy storage, general aviation and other industries, and support enterprises to vigorously develop new business forms such as professional services and value-added services in the fields of Internet of things, energy-saving and environmental protection services, new energy application, information services, new energy vehicle promotion. It should strengthen the construction of the standard system and improve the market access system to create a fair competition environment for the development of various enterprises.

\section{5 establish and improve the policy system of strategic emerging industries and innovate support methods}

The development of strategic emerging industries needs huge capital investment. It should give full play to the guiding role of central financial funds, the incentive role of national tax policies and the supporting role of multilevel capital market, establish and improve the policy system and support methods. It is embodied in the following aspects: first, in terms of financial support policies, and should increase financial input, give full play to the role of central financial funds in guiding and mobilizing the enthusiasm of social investment, establish a stable growth mechanism of financial investment, and guide the development of venture capital. Second, in terms of tax incentive policy, aiming at the characteristics of high proportion of human capital, R \& D expenses and difficulty in entering the market in the early stage of product development, it should improve the tax incentive policy, focus on the implementation of the existing tax policies to promote the investment in science and technology, the transformation of scientific and technological achievements and support the development of high-tech industries It is necessary to formulate flow support policies to form a policy means of universal incentives for social resources to develop strategic emerging industries. Third, in terms of financial policy, in view of the characteristics of a large number of innovative small and medium-sized enterprises in the early stage of the development of strategic emerging industries, such as venture capital, over-the-counter transactions, bond issuance and other direct financing support and policybased financing support, we should strengthen financial service support, focus on encouraging financial institutions to increase credit support, actively play the financing function of multi-level capital market, and vigorously develop innovation Industry investment and equity investment funds.

\section{6 deepen international cooperation, cultivate and develop international strategic emerging industries}

From the perspective of deepening international cooperation, China cultivates and develops strategic emerging industries. First of all, according to the "knowledge intensive" characteristics of strategic emerging industries, it should highlight the role of "attracting talents and talents", and make full use of global innovation resources, strengthen international scientific and technological exchanges and cooperation, and jointly create and share international innovation achievements. Secondly, according to the characteristics of high investment and high risk in strategic emerging industries, it should highlight the importance of using global capital, effectively improve the quality and level of international investment and financing cooperation, guide foreign investment to strategic emerging industries, encourage Chinese enterprises to invest and finance overseas, and effectively utilize foreign funds at multiple levels. Thirdly, it should adapt to the needs of China's strategic emerging industries to become stronger and bigger. Under the current situation that the international division of labor of strategic emerging industries has not yet been fully formed, we should promote the "going out" of technology and products, promote the transnational operation of enterprises, open up the international market, and participate in the international division of labor at a higher level.

\section{Conclusion}

In recent years, China attaches great importance to the development of strategic emerging industries, and has issued a number of policy documents. The state further puts forward the realistic goal of giving priority to the 
cultivation and development of strategic emerging industries and building new pillars of the industrial system. Under the influence of the national and local government's macro policies and the cooperation of enterprises and capital markets, the development of strategic emerging industries has shown some obvious characteristics, such as the growing scale, the strong growth of key areas, the efficient gathering of factors, the continuous improvement of innovation ability and the continuous improvement of policy environment, which has fully played the engine role of leading the high-quality economic development. The 14th five year plan will be a critical period for the development of strategic emerging industries. It should seize the opportunity, so as to provide support for the highquality and sustainable development of China's economy.

\section{Acknowledgment}

This work was financially supported by Foshan social science planning project in 2020, 2020-QN11; Henan philosophy and Social Sciences Planning Project in 2019, 2019BJJ032; The social development project of Henan provincial key R \& D and promotion project (Science and technology tackling key problems) in 2019, project number: 515 . Thanks for the help.

\section{References}

1. Xue L, Zhao J. Toward agile governance: The pattern of emerging industry development and regulation [J]. Chinese Public Administration, 2019 (8): 28-34.

2. Chinese Institute of Engineering Development Strategies. Report on the development of strategic emerging industries in China in 2020 [M]. Beijing: China Science Publishing \& Media Ltd., 2019.

3. Su Q Y. The theory of "decoupling" between China and the United States and the "Samuelson Trap" [J]. World Affairs, 2019 (15): 52-53.

4. Zhu Ruibo. Cultivation and policy orientation of strategic emerging industries in China [J]. Reform, 2010 (03): 19-28.

5. Lin Xuejun. Research on the development and formation mode of strategic emerging industries [J]. China soft science, 2012 (02): 26-34. 